\title{
ANALYSIS OF PROFITABILITY RATES IN BANK CREDITING
}

\author{
Dragoş Ilie $e^{1}$
}

\begin{abstract}
This paper aims to analyze rates of return for the diagnosis of an economic entity aiming to be credited. The methodology used consists in reporting some impact on work or certain balance sheets. The main results of research lead to the conclusion that on the one hand, rates of return analysis should be correlated with other indicators of economic activity at the trader level in order to reflect a more complete picture of the activity, and on the other hand, that the role of profit should not be fetishized.
\end{abstract}

Key words: economic profitability, financial profitability, commercial profitability, real return on equity

JEL codes: G32

\section{Introduction}

Profitability indicators are part of the efficiency indicators expressing the results of an activity as a ratio between the effects and efforts. The essential role in calculating the profitability as the ratio between effect and effort lies for the profit that is reported to various elements of an asset of the economic balance sheet. Why rates of return? Because profit, in its absolute value, should not be fetishized. A rational analysis involves quantifying the contribution of various balance sheet factors relevant to the achievement of profit, providing information about their ability to generate profit (Ilie, 2011).

Profitability is therefore the capacity of an economic agent to make profits, profitability indicators revealing the extent to which certain components of the activity contribute to the achievement of this profit (Huminiuc, 2008). The determination of return rates originates in the struggle for survival on the market, while requiring a need to compare with certain levels considered optimal in the branches of the activity. To obtain 100 lei profit compared to 130 lei profit obtained by another trader, says nothing. But if we know that the 100 lei were made with an investment effort of 50 lei and that the 130 lei were made with a 30000 lei investment effort, things change radically. The one who received 100 lei profit is more profitable than the one who received 130 lei profit.

In the financial theory and practice multiple rates of return are operated (Richard, 1989) the most commonly used are: rate of economic return, rate of financial profitability, rate of commercial profitability and the rate of profitability on resources consumed.

The levels of rates of return, considered to be universally accepted as fair, differ from branch to branch. Thus, in trade, construction, wood processing industry, their values are higher, however in metallurgy, mining, given the large amount of advanced capital, returns are lower. These levels suggested as being fair are found in Regulation 7/2003 on amending and supplementing Regulation 5/2002 on the classification of loans and investments as well as to the construction, adjustment and use of specific credit risk provisions. We consider the following levels of return as widely accepted for different sectors of the national economy: trade between 6 and 9\%; chemistry between 3 and $6 \%$, the mining industry between 3 and $4 \%$, equipment industry 3 to $6 \%$, transport 3-6\%; leather industry 5-7\%, 3-6\% agriculture, construction 4-8\%, metallurgy 3-4\%, wood industry $4-8 \%$, leasing 3-6\%.

\footnotetext{
${ }^{1}$ Spiru Haret University, Craiova, Romania, e-mail: dragosilie2002@yahoo.com
} 


\section{Analysis of rates of return through the rate method}

Both economic theory and in practice, there are several ways in which we can calculate the economic profitability. In principle it is determined as the ratio between total profit and asset or capital driven in order to produce profit (Petrescu and Mironiuc, 2002).

A first way of calculating economic profitability $(\mathrm{Re})$ is the ratio between total profit $(\mathrm{Pt})$ and total asset (At) as such:

$$
R_{e}=\frac{P_{t}}{A_{t}} 100
$$

The total profit incorporates the profit in the operating activity, in the financial activity and the exceptional activity. The total asset includes fixed assets and current assets. Fixed assets include: intangible assets (establishment costs and research and development expenses, current assets, provisions for the depreciation of intangible assets), tangible assets (lands, buildings, special constructions, machinery and other tangible assets, fixed assets in progress, provisions for the depreciation of tangible assets), financial assets (equity and other fixed assets, fixed receivables, provisions for the depreciation of financial assets); trade receivables with a maturity over one year. Current assets include: stocks of raw materials, supplies, inventory, inventory items, stocks held by third parties, production in progress, products, animals, goods, customers, and similar accounts, other receivables, debtors suppliers, settlements with associates on capital, regulation and related accounts, investment securities, bank accounts, the counter. We intentionally did this description of the total asset. The aim was to make it clear that economic profitability is the ability of all that a trader has to make profit.

A second way to determine the economic rate of return $(\mathrm{Re})$ is the ratio between the operating profit (Pe) and operating assets (Ae) as such (Zaman and Geamănu, 2006):

$$
R_{e}=\frac{P e}{A e} 100
$$

This way of calculating the rate of return is extremely important because it reduces the ability to create profit in the respective operating asset, namely in the core business of the trader (Brezeanu, 1999). In the analysis rating system of the banks for granting loans, this is the first indicator of profitability calculated, because the other two activities (financial and exceptional), although they may bring profit, derive from the basic activity and may be temporary. There are many practical situations, when, in order to get bank loans, traders increase their profit in recent months due to the accounting operations of exceptional activities. This is strictly charged by banks by calculating the profitability indicator as above. Using the operating profit allows the calculation of the rate of return independently of the extraordinary flows, of capital structure and tax policy.

A third way of determining the economic rate of return $(\mathrm{Re})$ is by considering the gross operating surplus (EBE) such as:

$$
R_{e}=\frac{E B E}{A_{t}} 100
$$

The gross operating surplus is obtained by deducting from the value added plus operating subsidies, staff costs and taxes. The largest share of the gross operating surplus is represented the value added as surplus of income over consumption value, as wealth created by the capitalization of the company's total asset. Since the gross operating surplus does not include depreciations and provisions, the rate of return calculated is independent of capital depreciation policy. 
A fourth way of determining the economic rate of return $(\mathrm{Re})$ takes into account the total profit $(\mathrm{Pt})$ and permanent capital $(\mathrm{Kp})$ as such:

$$
R_{e}=\frac{P_{t}}{K_{p}} 100
$$

The higher the indicator, the greater capital capacity it reflects in order to create permanent profit.

In international practice and theory, the economic rate of return is calculated as such (Moroşan, 2006):

$$
R O A=\frac{E B I T}{T A}
$$

Where:

$\mathrm{ROA}=$ economic rate of return

$\mathrm{EBIT}=$ result before taxes and interest payment

$\mathrm{TA}=$ total asset

This indicator is highly used by banks in the analysis of bank crediting. Including interest in the result obtained, banks have a more accurate image on the ability to pay interest to the trader, such calculated indicator excluding the risk of default interest. Also by including taxes in the result, banks have an incentive that the operator pays taxes to the state budget, in order not to be in a position to have his accounts blocked from founding attachments. Blocked accounts would be equivalent to blocked activity at the level of financial and supply flows, with repercussions on bank loan repayment.

The size of the economic rate of return drives a multitude of factors such as: sales structure, sales unit price, unit costs, current assets turnover, return on fixed assets, and return on current assets.

Suppose a trader from the trade industry recorded at the end of the financial year the following balance sheet structure of assets, liabilities and profit and loss account

- gross operating surplus 56.103 lei

- operating profit 36.709 lei

- total profit 26.161 lei

- profit before tax and interest payment 37.354 lei

- operating asset 251.000 lei

- total asset 279.493 lei

- permanent capital 108.941 lei

Economic rates of return using the above formulas become:

$$
\begin{gathered}
R_{e}=\frac{P_{t}}{A_{t}} 100=\frac{26.161}{279.493}=9 \%(6) \\
R_{e}=\frac{P_{e}}{A_{e}} 100=\frac{36.709}{251.000}=14 \%(7) \\
R_{e}=\frac{E B E}{A_{t}} 100=\frac{56.103}{279.493}=20 \%(8)
\end{gathered}
$$




$$
\begin{gathered}
R_{e}=\frac{P_{t}}{K_{p}} 100=\frac{26.161}{108.941}=24 \% \\
R_{e}=\frac{E B I T}{T A} 100=\frac{37.354}{279.493}=13 \%
\end{gathered}
$$

The first result of $9 \%$ includes the trader in the limits presented in the introduction for the branch of trade, being considered a good level of profitability since it has been engaged in retail sales in one commercial space. The $14 \%$ level of profitability in the operating activity is considered normal compared to the previous activity because at the level of operating activity, the profit is higher than the total profit. This is due to obtaining financial and exceptional losses. The profitability level of $13 \%$ is considered good by the bank because it is above the accepted level presented in the introduction.

Financial return (Rf) reflects the capacity of one's own capital to produce profit (Dumitrean, 1996), being determined as the ratio between the net profit $(\mathrm{Pn})$ and own capital (Kpr) as:

$$
R_{f}=\frac{P_{n}}{K_{p r}} 100
$$

Conducting an economic activity involves the allocation of own capital and borrowed capital. The category of own capital includes: social capital (subscribed paid, overhead assets), the private entrepreneurs' account (cash contribution, contribution in kind), premiums related to capital, reserves, reported result, result of the year, funds and distributions to development funds. Capitals, whether one's own or borrowed imply certain costs. If the rate of financial return is greater than the cost of own capitals, then their owners can benefit from additional value.

Net profit represents a highly relevant indicator of socio-economic performance, its economic future depending of its method of distribution. Net profit can be distributed either for the conservation of results or for distributing results. When conservation is chosen then the results can be achieved through the establishment of reserves required by law, reserves required by statute and reserves decided by the general assembly of shareholders. If you choose to distribute the results then this can be achieved by giving dividends for ordinary or preferred shares, bonuses granted to staff, etc. Conservation of results ensures protection and self-financing, while distribution remunerates owners of capital.

The higher the indicator, the better capacity it reflects in order to create profit.

In practice there are situations where the composition of own capitals also includes revaluation differences, investment subsidies and regulated provisions. In this case the indicator value is lower and is calculated as such:

$$
R_{f}=\frac{P_{n}}{K_{p r l}} 100
$$

Where:

$\mathrm{Rf}=$ financial profitability

$\mathrm{Pn}=$ net profit

Kprl = broad equity

Suppose a trader has the following balance sheet structure on liabilities - equity 200 lei, entrepreneur account (cash contributions) 300 lei, entrepreneur account (contribution in kind) 300 lei, reserves5628 lei, reported results 70255 lei, revaluation differences 1000 lei, investment 
subsidies 5000 lei, regulated provisions 400 lei, net profit 14967 lei. Financial profitability of the trader is:

$$
\begin{aligned}
& \text { 1) } R_{f}=\frac{P_{n}}{K_{p r}} 100=\frac{14.967}{200+300+300+5628+70255} 100=19,5 \% \\
& \text { 2) } R_{f}=\frac{P_{n}}{K_{p r l}} 100=\frac{14.967}{76.683+1000+5000+400} 100=18,01 \%
\end{aligned}
$$

The rate of return in the second case is lower because the calculation of capital and revaluation differences, regulated provisions and investment subsidies were taken into account.

Among the factors used in the management process to increase the financial profitability we include: increasing profits, own equity and borrowed equity structure and the rotation speed of current assets. The higher the rotation speed of current assets (while maintaining unit profit per product) the higher the total profit will be and will increase the financial return. Current assets turnover varies from branch to branch, being higher in the trade branch and lower in heavy industry.

However, increasing financial profitability must be sought in the distribution of net profit. Allocation of net profit for the increase of own represents the foundation of financial profitability. Provisioning at the level of economic trader has a clearly defined economic justification, representing a measure of protection in the process of capitalization (Elias, 2005). Any loss achieved by the company at the end of a year can reduce equity and can cause severe imbalance in the process of capital accumulation. The reserves constituted protect the erosion of capital caused by losses.

Given the importance of building up reserves, the law states its obligation of 20 percent of the share capital as legal reserves. This percentage can be considered as too small, given the need to maintain an appropriate level of own capital in the economic activity.

It is preferable to increase this percentage to 35 percent and thus strengthening the state's role in the process of capitalization through legislative measures. Incorporating profits in capitals is a proof of maturity in the knowledge of market games, since that instead of receiving dividends used for personal needs, shareholders leave the company decide their capitalization.

Commercial profitability (Rc) provides the link between profit and turnover, in practice there are several ways to determine it.

A first way reports gross profit $(\mathrm{Pb})$ in turnover $(\mathrm{CA})$

$$
R_{c}=\frac{P_{b}}{C A} 100
$$

The higher the indicator value, the greater the profit obtained in a certain volume of turnover. In accounting terms, turnover includes the balance of accounts 701, 702, 703, 704, 705, 706, 707, 708 on revenues from the sale of finished products, revenues from the sale of semifinished products, revenues from the sale of residual products, revenues from works and services performed, revenues from studies and research, revenues from fees, locations and rents, revenues from selling goods and revenues from various activities.

A second way of determining commercial profitability $(\mathrm{Rc})$ is by reporting net profit $(\mathrm{Pn})$ in turnover (CA) as such:

$$
R_{c}=\frac{P_{n}}{C A} 100
$$


The amount calculated will be lower than in the first case because gross profit was corrected with the income tax. Experts recognize that this commercial rate of return has limited information value because net profit is influenced by the financial and exceptional results and by the company's fiscal policy. Yet they recognize the importance of the commercial rate of return if it is correlated with the analysis of economic profitability and financial profitability.

A third method of calculation reports the gross margin $(\mathrm{Mb})$ in turnover (CA)

$$
R_{c}=\frac{M_{b}}{C A} 100
$$

The gross margin represents the difference between turnover and cost of sales. It is also found under the title of operating profit (Moroşan, 2006) in speciality literature. Cost of sales is the purchase price of goods sold, the production cost of finished goods sold, works performed and services provided by third parties. The calculation of the gross margin is performed in order to see if it covers the costs of distribution and financial expenses to be able to pay the owners of capital.

Several factors act on the gross margin volume, including: the volume of production obtained, the structure of production sold, unit cost of production, the price of sale per product, excluding VAT. For the increase of the gross margin, in the decision making process must be acted for: the practice of pricing based on enhancing product quality, reducing unit costs of production, marketing products with a higher profit margin compared to the company average, growth of production given that it has secured outlet.

Suppose a trader carries both a production activity and a trading activity, and at the end of the year he achieves the following total revenues:

- Revenues from sale of goods 1.300 .000 lei

- Revenues from sale of production 1.800.000 lei

- Revenues from work performed and services provided 100.000 lei.

The purchase cost of goods sold was 1,000,000 lei. The production cost of finished goods sold, works performed and services provided to third parties was 1.6 million lei. The gross profit of 150,000 lei is known and the income tax of 32,000 lei. Commercial rates of return become:

$$
\begin{gathered}
R_{c}=\frac{P_{b}}{C A} 100=\frac{150.000}{1.300 .000+1.800 .000+100.000} 100=4,68 \% \\
R_{c}=\frac{P_{n}}{C A} 100=\frac{150.000-32.000}{3.200 .000} 100=3,68 \% \\
R_{c}=\frac{M_{b}}{C A} 100=\frac{3.200 .000-2.600 .000}{3.200 .000} 100=18,75 \%
\end{gathered}
$$

Real capital is known in the speciality literature as fixed capital and working capital involved in the production process. The return on real capital (Rkr) expresses the real capital's capacity to obtain profit, being determined as the ratio between the operating profit $(\mathrm{Pe})$ and the average value of fixed capital $(\mathrm{KF})$ and working capital $(\mathrm{Kc})$.

$$
R_{K R}=\frac{P_{e}}{\overline{K_{f}}+\overline{K_{c}}} 100
$$


The considered income is the one from operations because this is the core business of the company, where the real capital is involved in creating added value. We believe that, when considering the real capital return, we must take into account the interdependence that exists between real capital and financial capital in the production process.

\section{Conclusions}

The analysis of rates of return must be correlated with other indicators of economic activity at the trader level in order to reflect a more complete picture of the activity. You should not omit the influence of time and the dynamic analysis of rates of return. A decreasing profitability in recent years reflects a decrease in the ability of the trader to obtain profit, involving finding the causes that led to this situation. A continuous decrease of profit (if not corrected in time) can lead to lack of liquidity, which when it becomes chronic, leads to bankruptcy.

In practice, rates of return levels are higher or lower, depending on each company's ability to make profit, but excessive levels, compared to what is considered a normal level, can be sanctioned in practice. Therefore, banking units, when analyzing the profitability of a trader and when the indicator has a value of $80 \%$, will consider it a certain matter of conjecture (if true) or will deepen the analysis even more. Such an exceedingly high level will certainly be downgraded in the rating or scoring made by the bank.

\section{References}

1. Brezeanu P., 1999. Financial management of the enterprise in market economy, Bucharest, România de Mâine Foundation Publishing House

2. Dumitrean E., 1996. Balance sheet, Iaşi, A.92 Publishing House

3. Huminiuc C.,2008. Analysis of rates of return through the rates method, Studia Universitatis Vasile Goldiş Arad, vol.18, part III, p.13-19

4. Ilie D., 2005. Sustainable crediting, Craiova, Sitech Publishing House

5. Ilie D., 2011. Economic efficiency the fundament of economy crediting, Craiova, Universitaria Publishing House

6. Moroşan I., 2006. Economic and financial analysis, Bucharest, România de Mâine Foundation Publishing House

7. Petrescu S., Mironiuc M., 2002. Economic and financial analysis, Iaşi, Tiparul Publishing House

8. Richard J., 1989. Les moyens de l'analyse des performances, Paris, Imprimerie Vic Services

9. Zaman G., Marinela, G., 2006, Economic efficiency, Bucharest, România de Mâine Foundation Publishing House 